\title{
CO-INFECTION BY SEMLIKI FOREST VIRUS AND MALARIAL PARASITE MODULATES VIRAL MULTIPLICATION, PATHOGENESIS AND CYTOKINES IN MICE
}

\author{
GUPTA P.***, SETH P.***, HUSAIN M.M.*, PURI S.K.**** \& MAHESHWARI R.K.***
}

\section{Summary:}

Environmental, technological and societal factors continue to have a dramatic effect on infectious diseases worldwide and are considered to be facilitating the emergence of several infectious diseases at a time. Co-infection with different species of viral and malaria infections are currently emerging problems of dual infection in the developing as well as developed countries. Understanding of interactions between the host, malaria and virus infection is of current concern and we have initiated studies to delineate the mechanisms involved during the progression of Semliki forest virus (SFV) and Plasmodium yoelii (P. yoelii) infection in mice. Enhanced virus multiplication and up-regulation of cytokine mRNA level in P. yoelii and SFV co-infected mice were observed on day 4 post-infection compared to respective controls. Collectively, our observations indicate that malaria infection may influence virus multiplication, pathogenesis and up-regulation of cytokine mRNA during co-infection in mice.

KEY WORDS : co-infection, virus, malarial parasite, P. yoelii, pathology, cyłokine.

$\checkmark$ nvironment contains a great variety of infectious microbes that may be potentially damaging and threaten our survival. Malaria continues to be one of the main public health problems in the world, especially in most of the African countries. Sharma, (1999) indicates that malaria is prevalent in northeastern and peninsular India. At present 90 countries or territories in the world are considered malarious; almost half of them being in Sub-Saharian Africa (WHO, 1993, 1996, 1996 and 1997).

Human populations are often infected with more than one infection at a time especially in developing countries (Cox, 2001; Howard et al., 2001). Co-infection with different species of malaria and a number of viral infec-

* Industrial Toxicology Research Centre, Lucknow, India.

*** BSI, MOEF, Government of India, Kolkata, India.

**:* Uniformed Services University of Health Sciences, Bethesda, MD, USA.

***** Central Drug Research Institute, Lucknow, India.

Correspondence: M.M. Husain, Scientist 'F', Virology Laboratory, Industrial Toxicology Research Centre, P.O. Box No. 80, M.G. Marg, Lucknow (UP) 226 001, India.

E. mail: husainmm@rediffmail.com
Résumé : Co-Infection par le virus de la Forêt de Semliki et PLASMODIUM YOELII CHEZ LA SOURIS : MODULATION DE LA MULTIPLICATION VIRALE, DE la PATHOlogie ET DE LA PRODUCTION DE CYTOKINES

De nombreux facteurs environnementaux, technologiques et sociétaux ont des répercussions importantes sur les maladies infectieuses dans le monde, et sont considérés comme favorisant l'émergence de plusieurs d'entre elles. Les co-infections par des virus et les parasites du paludisme constituent des problèmes nouveaux de santé publique aussi bien dans les pays développés que dans ceux en développement. Une meilleure compréhension des interactions entre l'hôte et les infections palustres et virales est nécessaire. Nous avons démarré des travaux visant à mieux cerner les mécanismes impliqués dans la progression de l'infection par le virus de la Forêt de Semliki (SVF) et Plasmodium yoelii chez la souris. Quatre jours après l'infection, la multiplication virale et le niveau de certaines cytokines étaient plus élevés chez les souris co-infectées par rapport aux contrôles respectifs. Nos observations indiquent que l'infection palustre peut avoir une influence sur la multiplication virale, la pathogenèse et la production de cytokines lors d'une co-infection avec un virus.

MOTS CLÉS : co-infection, virus, parasite, malaria, P. yoelii, pathologie, cytokine.

tions are frequent and this may impact an outcome and clinical manifestation. Non lethal strains of Plasmodium yoelii (P. yoelii) and P. chabaudi became lethal in mice infected with Rowson Parr virus (Cox et al., 1974). Similarly, Epstein Barr Virus, which normally causes mild infections, would contribute to the development of Burkitt's lymphoma in individuals exposed to malaria (De Thé, 1985). Likewise, chronic infection with hepatitis B virus (HBV) may be a risk factor for severe malaria (Barcus et al., 2002). Malaria infection influence the course and pathogenesis of HBV infection in co-infected mice/humans (Pasquetto et al., 2000). Higher HIV-1 blood viral burden was recorded in patients with Plasmodium falciparum malaria (Hoffman et al., 1999). An association between HIV1 infection and clinical malaria has been reported from Africa (Hoffman et al., 1999; Francesconi et al., 2001; Ter Kuile et al., 2004). P. falciparum infection modulates HIV-1 pathogenesis by activating lymphocytes and stimulating viral replication through production of cytokines (Xiao et al., 1998). Increased risk of malaria occurrence in HIV-infected pregnant women was reported in a cohort study (Ladner et al., 2002). 
Cohen (2003) has reported spread of malaria in HIVinfected pregnant women and found that co-infection with malaria significantly increased a mother's risk of transmitting the AIDS virus to her baby before or during birth.

Co-infection with virus and malaria and other pathogens is an emerging problem. Understanding the various aspects of interactions between the host, virus and malarial parasite infection involving modulations in their infectivity, augmentation of the histopathology of infection and delineation of the mechanisms involved are the objective of the present investigation. A "Virus-malarial parasite mouse model" influencing dual infection with Semliki forest virus (SFV) and $P$. yoelii was used. SFV causes acute infection of central nervous system producing encephalitis. The virus replicates in different organs, tissues and within the CNS by infecting neurons (Smithburn \& Haddow, 1944).

\section{MATERIALS AND METHODS}

\section{ANIMALS, VIRUS AND CELLS}

$\circlearrowleft$ wiss albino mice (10-12 gm. Body wt.) obtained from the Industrial Toxicology Research Centre breeding colony were maintained on a standard pellet diet and water ad libitum and were housed in environmentally controlled rooms (Temperature $25^{\circ} \mathrm{C} \pm 2$ and humidity $50 \pm 5 \%$ ) under a $12 \mathrm{~h}$ dark light cycle. All procedures, maintenance and treatment of mice were in accordance with the guidelines for the care of animals by the Institutional Animal Ethics Committee.

\section{VIRUS}

Semliki forest virus (Smithburn and Haddow strain) obtained from American Type Culture Collection (ATCC), USA was passaged intracerebrally in Swiss mice (6-7 g). Mice showing moribund infectivity symptoms and typical hind limb paralysis were sacrificed and brain tissue was aseptically excised, homogenized and centrifuged at 5,000 rpm for 30 minutes. Supernatant serving as stock virus was stored at $-80^{\circ} \mathrm{C}$.

\section{CELl LINE}

Baby hamster kidney (BHK-21) cell line obtained from National Centre for Cell Science (NCCS), Pune, was used for in vitro viral titration. Cells were grown in Minimum Essential Medium (MEM, Sigma, USA) supplemented with $10 \%$ fetal bovine serum (FBS, Sigma, USA) and antibiotics (streptomycin $100 \mu \mathrm{g} / \mathrm{ml}$, benzyle penicillin 100 units $/ \mathrm{ml}$ and gentamicin $40 \mu \mathrm{g} / \mathrm{ml}$ ) and maintained in MEM containing $2.5 \%$ FBS and antibiotics.

\section{VIRUS TITRATION}

Brain tissue was homogenized $(10 \% \mathrm{w} / \mathrm{v})$ in plain MEM, centrifuged at 5,000 rpm for 30 minutes, supernatant filtered by micro filter (Millipore, USA) and diluted. Several dilutions of virus samples were adsorbed on BHK-21 cell monolayer in 96 well microtitre plate, incubated for $48 \mathrm{hrs}$. at $37^{\circ} \mathrm{C}$ in humid atmosphere of $5 \% \mathrm{CO}_{2}$ incubator (Heraeus Hera Cell model, Germany). The plates were later stained with $0.1 \%$ crystal violet and examined under an inverted microscope for determination of virus titre by cytopathic effect assay as described earlier (Gupta et al., 2002). Cytopathic effect was graded on the standard scale of normal to virtually complete destruction of cell monolayer.

\section{PARASITE}

Plasmodium yoelii (P. yoelii) nigeriensis strain was used throughout the experiment. P. yoelii N-67 strain was maintained by serial blood passage as well as by transmission through mosquito vector, Anopheles stephensis.

\section{PARASITAEMIA}

Thin blood smears from $P$. yoelii infected mice were prepared taking a drop of tail blood. Fixed smears were stained with Giemsa stain and erythrocytes were observed for infected cells. Degree of parasitaemia was recorded as infected cells per 100 erythrocytes.

\section{TREATMENT}

Four groups of mice, ten in each group, were arranged and treated as control, given saline only; SFV control, infected subcutaneously with virus; P. yoelii control, infected intraperitoneally with malarial parasite and the experimental group, challenged with SFV and $P$. yoelii simultaneously. Three mice from each group were withdrawn and sacrificed on day 2 and day 4 postinfection for cytokine-mRNA analysis, virus titration in brain tissue and histopathological studies.

\section{RIBONUCLEASE PROTECTION ASSAY OF CYTOKINES}

We analyzed the expression of cytokine mRNA levels in brains of mice in all four groups using the Riboquant Multiprobe Ribonuclease Protection Assay (RPA) kit (Pharmingen, San Diego, CA, USA). Animals from each group were sacrificed on $4^{\text {th }}$ day post-infection and brains were collected, snap-frozen, and stored at - $80^{\circ} \mathrm{C}$. RNA was isolated from the frozen tissue samples using Trizol (Life Technologies Inc., USA), quantitated and equalized on formaldehyde agarose gels. For RPA, the protocols used were according to the manufacturer's instructions. Briefly, $20 \mathrm{mg}$ of each RNA sample was hybridized at $56^{\circ} \mathrm{C}$ for $12-14 \mathrm{~h}$ with a ${ }^{32} \mathrm{P}-$ 
UTP-labled probe. The probe was prepared by transcribing the mouse cytokine mck-2b template set using T7 RNA polymerase. After hybridization, samples were subjected to Rnase digestion for $45 \mathrm{~min}$. at $30^{\circ} \mathrm{C}$. Ribonuclease-protected bands were then resolved on denaturing urea-PAGE gels, followed by autoradiography. The template used allowed us to study the differential regulations of IL- $12 \mathrm{p}^{35}, \mathrm{IL}-12 \mathrm{p}^{40}$, IL-10, IL- $1 \alpha$, IL-1 $\beta$, IL-1Ra, IGIF, IL-6, IFN- $\gamma$, macrophage inducing factor (MIF), L-32 and glyceraldehyde 3-phosphate dehydrogenase (GAPDH) mRNAs served as housekeeping gene controls in the assay, to assure equal loading of RNAs.

\section{Histopathology}

To evaluate tissue damage, formalin fixed and paraffin embedded section of brain tissue were prepared from all four groups of mice, stained with hematoxylin and eosin ( $\mathrm{H} \& \mathrm{E}$ ) and examined microscopically for infection-induced lesions.

\section{STATISTICAL ANALYSIS}

The data was analyzed statistically by Student's t-test for level of significance and presented as mean \pm SE. Probability value ( $p$ value) was derived to represent the significant difference between the two groups.

\section{RESULTS AND DISCUSSION}

Studies with SFV and $P$. yoelii showed an enhanced virus titre in the brain of mice challenged with SFV and infected with $P$. yoelii as compared to control on post infection ( $\mathrm{p}<0.001$ ) (Fig. 1). Peritoneal blood parasitaemia was more elevated on day 4 in the group of mice co-infected with SFV and P. yoelii (p < 0.001) (Fig. 2). Cytokine profiles were studied using RPA kit. This showed that SFV infection led to up-regulation in mRNA levels of two cytokines. Expression of IL-IRa and IGIF was detected in SFV $+P$. yoelii co-infected mice brain and was not evidenced in the $P$. yoelii group or

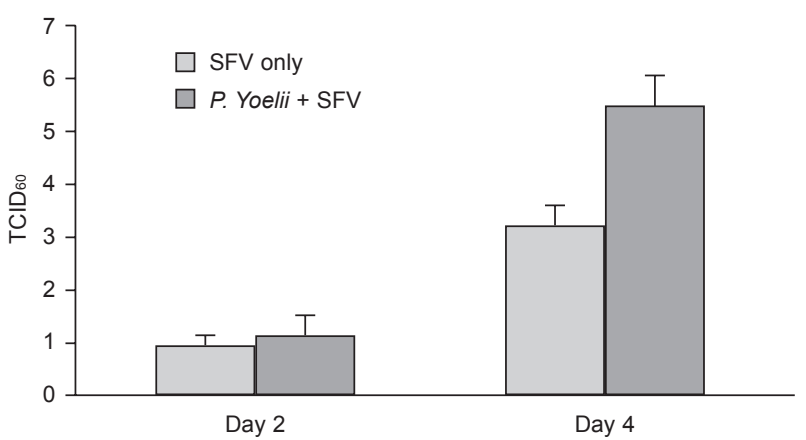

Fig. 1. - Virus titre in mouse brain. (Bar represent \pm SE, 10 animals in each group).

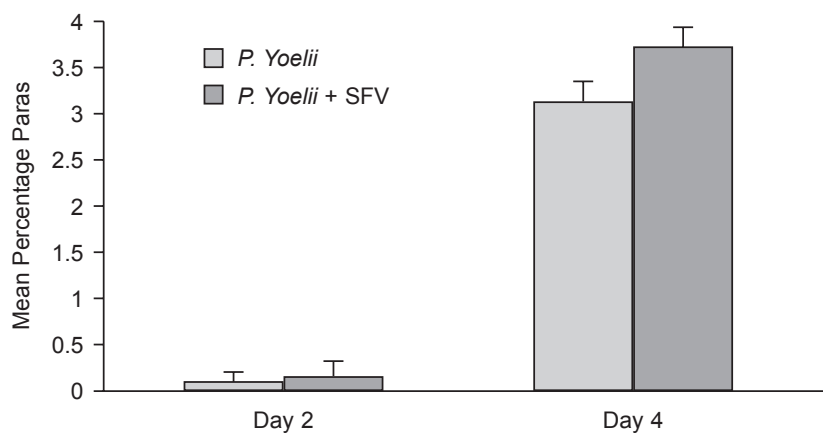

Fig. 2. - Parasitaemia in mouse blood. (Bar represent \pm SE, 10 animals in each group).

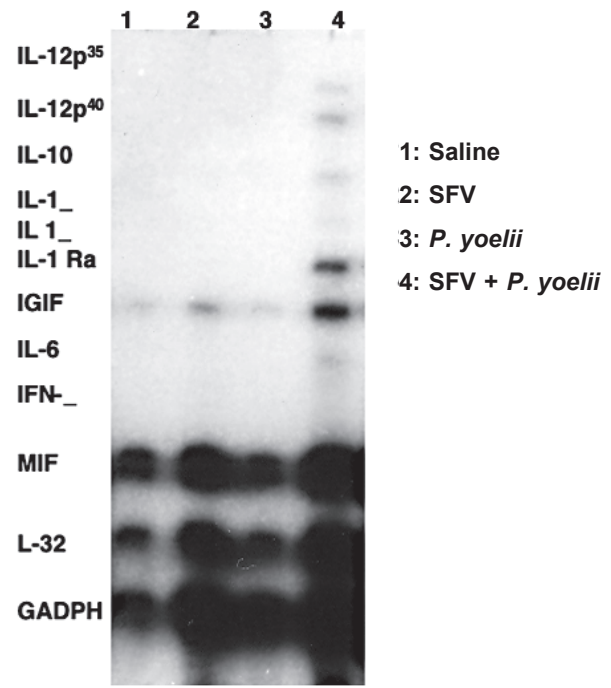

Fig. 3. - Cytokine profile of mouse brain on day 4 post-infection.

the saline group (Fig. 3). A lower level of IGIF mRNA was observed in SFV infected mice brain.

Histopathological analysis of the brain showed intact meningeal covering of cerebral cortex on day 4 after saline treatment (Fig. 4A). Meningeal oedema and necrotic debris in brain were present on day 4 following SFV infection (Fig. 4B). P. yoelii alone caused meningeal congestion (Fig. 4C). However, co-infection with SFV and $P$. yoelii caused marked meningeal congestion / greater meningitis and cortical degeneration (Fig. 4D). Overall the intensity of inflammation and cortical destruction was higher in the tissues of animals co-infected with $\mathrm{SFV}+P$. yoelii when compared with single infection.

Cytokines are important mediators in inflammatory pathology of the central nervous system (CNS), including encephalitis and demyelinating diseases. Since IL1 Ra has been suggested to play a role in pathogenesis of viral infections, it is likely that $P$. yoelii accelerates viral multiplication through its up-regulation. Up-regulation in mRNA level of cytokine IL-1Ra in brain of mice co-infected with SFV and $P$. yoelii support above 

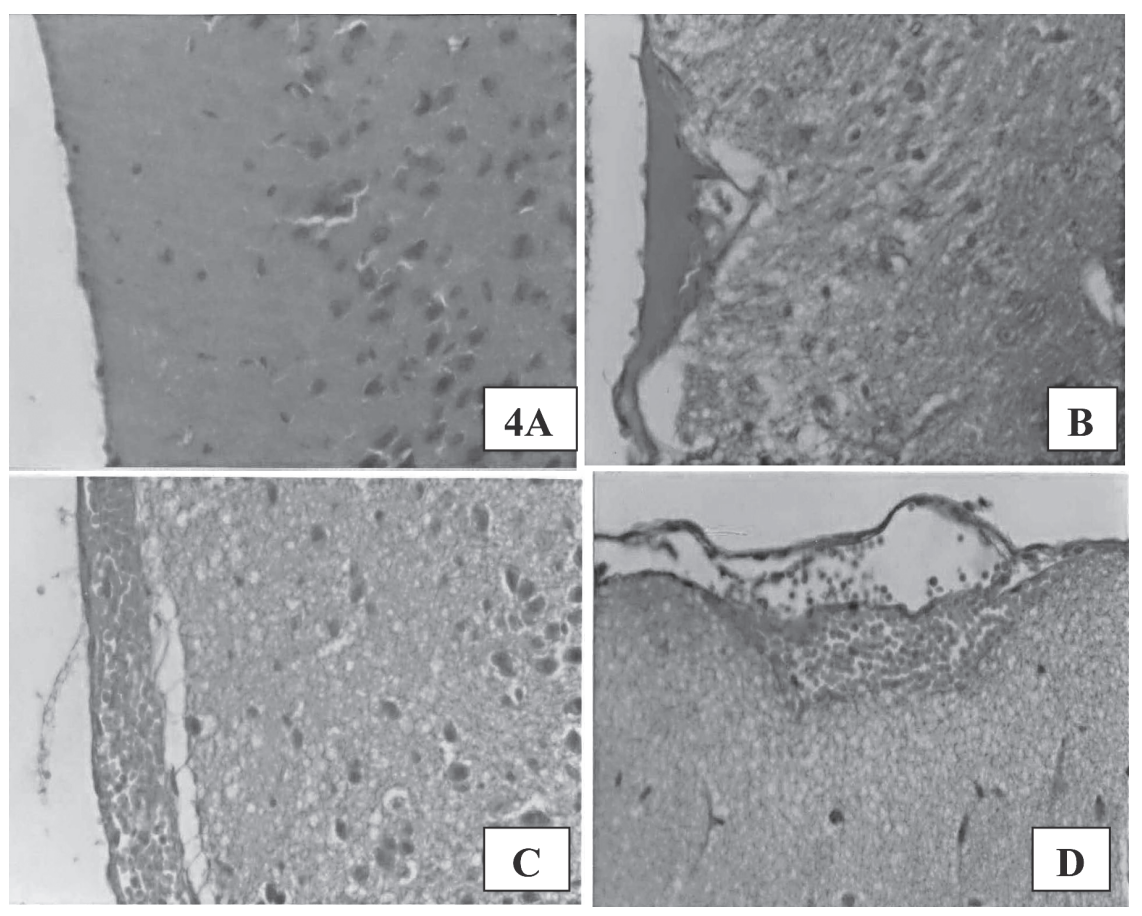

Fig. 4A. - Mouse brain at 4 days after saline treatment showing intact meningeal covering of cerebral cortex.

B. - Mouse brain at 4 days after sub-cutaneous challenge of SFV exhibiting oedematous reaction in meninges.

C. - Mouse brain at 4 days after intraperitoneal infection of $P$. yoelii demonstrating meningcal congestion.

D. - Mouse brain at 4 days after coinfection with SFV (sc) followed by $P$. yoelii (ip) showing marked meningeal congestion and moderate cortical degeneration. contention. Recently, Haque et al. (2004) have demonstrated up-regulation of cytokine mRNA expression in the spleen and lungs of Balb/c mice infected with $P$. yoelii and MHV.

Co-infection of the host may have different consequences for each of the infectious agents. In mixed infections, the burden of one or both the infectious agents may be increased, one or both may be suppressed or one may be increased and the other suppressed. Immunosuppression in mice and humans was reported to be characteristically associated during malaria infection. Enhancement of virus titre in co-infected animals is explainable in these terms.

Freitag et al. (2001) have shown that malaria infection induces virus expression in human immunodeficiency virus transgenic mice by CD4T cell-dependent immunoactivation. Pasquetto et al. (2000) reported host virus interactions during malaria infection in hepatitis B virus. Wabwire et al. (2001) have shown the effect of HIV-1 infection and malaria parasitemia. All these studies support our contention that co-infection with malaria or other parasites may enhance viral multiplication. Although the observations are of preliminary nature, however, the implications of the present investigation are indicative of far reaching effects and adds new dimension to the problem of predisposition to viral and malaria coinfection and in-depth studies are required to understand host-virus and malarial parasite interaction since multiple infections may have important implications for designing control programmes against parasitic diseases.

\section{ACKNOWLEDGEMENTS}

U

TS India Fund supported this work for Cultural Educational and Scientific Cooperation for project No. N-904-660.

\section{REFERENCES}

Barcus M.J., Hien T.T., White N.J., Laras K., Farrar J., Schwartz I.K., Corwin A. \& Baird J.K. Hepatitis B infection and severe Plasmodium falciparum malaria in Vietnamese adults. American Journal of Tropical Medicine and Hygiene, 2002, 66, 140-142.

COHEN J. Mothers's malaria appears to enhance spread of Aids Virus. Science, 2003, 302, 1311-1321.

Cox F.E.G., Wedderburn N. \& Salaman M.H. The effect of Rowson-Parr virus on the severity of malaria in mice. Journal of General Microbiology, 1974, 85, 358-364.

Cox F.E.G. Concomitant infections, parasites and immune responses. Parasitology, 2001, 122, S23-S38.

De ThÉ G. Eppstein-Barr virus and Burkitt's lymphoma worldwide, the causal relationship revisited. In: Burkitt's lymphoma: A human cancer model, Lenoir G.M, O'Conor G.T. \& Olweny, C.L.M. (Eds). Lyon: IARC Scientific Publication No. 60, 1985, 165-176.

Freitag C., Chougnet C., Schito M, Near K.A., Shearer G.M., LIC L.J. \& SHER A. Malaria infection induces virus expression in human immunodeficiency virus transgenic mice by Cd4t cell-dependent immune activation. Journal of Infectious Diseases, 2001, 183, 1260-1268.

Francesconi P., Fabiani M., Dente M.G., Lukwiya M., Okwey R., Ouma J., OchaKachon R., Cian F. \& Declish S. HIV, malaria 
parasites and acute febrile episodes in Ugandan adults: a case-control study. AIDS, 2001, 15, 2445-2450.

Feiko O.T.K., Monica E.P., Francine H., Verhoeff V.U., Robert D., Newman A.M., Eijk V., Stephen J.R. \& Steketee R.W. The burden of co-infection with human immunodeficiency virus type 1 and malaria in pregnant women in sub-saharian Africa. American Journal of Tropical Medicine and Hygiene, 2004, 71, 41-54.

Gupta P., Husain M.M., Shankar R. \& Seth P.K. Lead exposure enhances virus multiplication and pathogenesis in mice. Veterinary and Human Toxicology, 2002, 44, 205-210.

Haque A., Rachinel N., Quddus M.R., Haque S., Kasper L.H. $\&$ UsHerwood E. Co-infection of malaria and $\gamma$-herpesevirus: exacerbated lung inflammation or cross-protection depends on the stage of viral infection. Clinical \& Experimental Immunology, 2004, 138, 396-404.

Hoffman I.F., Jere C.S., Taylor T.E., Munthali P., Deyer J.R., Wirima J.J., Rogerson S.J., Kunwenda N., Eron J.J., Fiscus S.A., Chakraborty H., Taha T.E., Conen M.S. \& Molejneux M.E. The effect of Plasmodium falciparum malaria on HIV1RNA blood plasma concentration. AIDS, 1999, 13, 487-494.

Howard S.C., Donnelly C.A. \& Chan H.S. Methods for estimation of association between multiple species parasite infection. Parasitology, 2001, 122, 233-251.

Ladner J., Leroy V., Simonon A., Karita E., Bogaerts J., De Clerce A., Van De Perre P. \& Dabis F. The pregnancy and HIV study group (EGE), HIV infection, malaria and pregnancy: a prospective chort study in Kigali, Rwanda. American Journal of Tropical Medicine and Hygiene, 2001, 66, 56-60.

Sharma V.P. Current scenario of Malaria in Indian. Parasitologia, 1999, 41, 349-351.

SmithbuRn K.C. \& Haddow A.J. Semiliki forest virus I. Isolation and pathogenic properties. Journal of Immunology, 1944, 49, 141-157.

Pasquetto V., Guidotti L.G., Kakimi K., Tsuji M. \& Chisari F.V. Host-virus interactions during malaria infection in hepatitis B virus transgenic mice. Journal of Experimental Medicine, 2000, 192, 529-535.

Xiao L., Owen S.M., Rudolph D.L., Lal R.B. \& Lal A.A. Plasmodium falcipharum antigen-induced human immunodeficiency virus type 1 replication is mediated through induction of tumor necrosis factor- $\alpha$. Journal of Infectious Diseases, 1998, 177, 437-445.

World Health Organization. A global strategy for malaria control. WHO, Geneva, 1993, 30.

World Health Organization. Management of uncomplicated malaria and the use of antimalarial drugs for the protection of travelers. WHO/MAL, 1996, 96-1075.

World Health Organization. Tropical diseases control. malaria in the world, 1996, CTD/TDT/96 12.

World HEALTH ORGaNizATION. Interregional meeting on malaria control with emphasis on drug resistance. Manila, Philippines, 1997.

Wabwire M.F., Gray R.H., Wawer M.J., Sewankambo N. \& SerWADDA D. HIV-1 infection and malaria parasitaemia. Lancet, 2001, 357, 233.

Reçu le 27 juin 2005

Accepté le 5 mai 2006 